\title{
Fetal and infant origins of asthma
}

\author{
Liesbeth Duijts
}

Received: 8 January 2012/Accepted: 30 January 2012/Published online: 18 February 2012

(C) The Author(s) 2012. This article is published with open access at Springerlink.com

\begin{abstract}
Previous studies have suggested that asthma, like other common diseases, has at least part of its origin early in life. Low birth weight has been shown to be associated with increased risks of asthma, chronic obstructive airway disease, and impaired lung function in adults, and increased risks of respiratory symptoms in early childhood. The developmental plasticity hypothesis suggests that the associations between low birth weight and diseases in later life are explained by adaptation mechanisms in fetal life and infancy in response to various adverse exposures. Various pathways leading from adverse fetal and infant exposures to growth adaptations and respiratory health outcomes have been studied, including fetal and early infant growth patterns, maternal smoking and diet, children's diet, respiratory tract infections and acetaminophen use, and genetic susceptibility. Still, the specific adverse exposures in fetal and early postnatal life leading to respiratory disease in adult life are not yet fully understood. Current studies suggest that both environmental and genetic factors in various periods of life, and their epigenetic mechanisms may underlie the complex associations of low birth weight with respiratory disease in later life. New well-designed
\end{abstract}

L. Duijts

Department of Epidemiology, Erasmus Medical Center,

Rotterdam, The Netherlands

L. Duijts

Department of Epidemiology and Pediatrics-division of Respiratory Medicine, Erasmus Medical Center, Rotterdam, The Netherlands

\section{Duijts $(\bowtie)$}

Division of Respiratory Medicine (Sp-3435),

Department of Pediatrics, Erasmus Medical Center,

PO Box 2060, 3000 CB Rotterdam, The Netherlands

e-mail: 1.duijts@erasmusmc.nl epidemiological studies are needed to identify the specific underlying mechanisms. This review is focused on specific adverse fetal and infant growth patterns and exposures, genetic susceptibility, possible respiratory adaptations and perspectives for new studies.

Keywords Cohort study $\cdot$ Foetus $\cdot$ Infant $\cdot$ Asthma $\cdot$ Low birth weight - Preterm birth · Growth - Smoke exposure . Maternal diet · Breastfeeding · Respiratory tract infections . Acetaminophen $\cdot$ Gene $\cdot$ Epigenetics

Asthma in childhood has a high prevalence across many countries worldwide [1]. The reported prevalence of asthma is around $5-10 \%$ among school-age children and figures are even higher for asthma related symptoms, such as wheezing, in younger children. Childhood asthma is related to a reduced quality of life and exercise tolerance, and higher risks of school absenteeism and hospitalization [2]. Despite the availability of effective treatments for symptoms, the morbidity remains high [3]. The lack of curative options seems to be largely due to the unknown aetiology of asthma [4]. Furthermore, one general definition of asthma is difficult to define [5]. Objective tests, including spirometry or bronchial hyperresponsiveness, are not easy to conduct in young children, and have limited applicability. In epidemiological studies it is currently well accepted that a diagnosis of asthma is based on parental- or self-reported symptoms [6]. Because of these different asthma definitions, it is important to identify the specific underlying mechanisms for the associations of exposures in fetal life and infancy with different asthma related outcomes, which might reflect different specific structural and functional adaptations.

Several studies, of which some have been published in the European Journal of Epidemiology have suggested that 
asthma, like other common diseases, has at least part of its origin early in life [4, 7-41]. Long term follow up studies in different populations have shown that impaired respiratory health or lung function in early childhood is associated with asthma and other respiratory diseases in later life [42-48]. These studies suggest that lung function and susceptibility for various respiratory diseases track from early childhood onwards. Thus, risk factors for wheezing and asthma or low airway function in childhood might predispose for respiratory diseases in later life. Examples of known major risk factors in early childhood for development of respiratory disease or low airway function include exposure to parental smoking or air pollution, no or shorter period of breastfeeding, obesity, larger family size, daycare attendance, infectious diseases in early childhood and acetaminophen use [49-56].

\section{Developmental origins of childhood asthma}

Recently, low birth weight has also been shown to be associated with increased risks of asthma, chronic obstructive airway disease, and impaired lung function in adults [57-61]. In term born children, it was found that low birth weight is associated with increased risks of respiratory symptoms in the first 7 years of life [62]. Low birth weight per se is not likely to be the causal factor leading to asthma. The same birth weight might be the result of various growth patterns and different fetal exposures [10, 63]. The developmental plasticity hypothesis suggests that the associations between low birth weight and diseases in later life are explained by early adaptation mechanisms in response to various adverse exposures in fetal life and early childhood [64]. This hypothesis is supported by extensive epidemiological evidence showing strong and consistent associations of low birth weight with the risk of common diseases in adulthood, including cardiovascular disease, type 2 diabetes and COPD [10, 64-66]. Developmental adaptations in fetal life and infancy might also result in impaired lung growth, leading to smaller airways, decreased lung volume, and subsequently to an increased risk of asthma or COPD throughout postnatal life [46, 58, $60,66,67]$. Reduced diameter of central and small airways can contribute to the development of childhood asthma [68-70]. Airway caliber is a key determinant of total airway resistance and might be related to asthma and COPD [71]. Other mechanisms underlying the associations of low birth weight with asthma and respiratory diseases in childhood and adulthood might include an innate or $\mathrm{T}$ helper 2 skewed immune system, increased allergen sensitization, inflammation and bronchial hyperreactivity [72-75]. These different underlying mechanisms may lead to various phenotypes of asthma with onset at different ages.

\section{Fetal growth characteristics}

Studies with information about fetal growth characteristics in different periods of pregnancy enable identification of critical fetal periods that might be important for the risk of asthma and other respiratory diseases [76, 77]. A recent study suggested no associations of fetal growth characteristics with the risk of 'ever wheeze' until the age of 3 years [78]. However, when the outcome wheeze was combined with atopic status of the child, the authors showed that a SD lower fetal head circumference growth between 11 and 19 weeks was associated with a $10 \%$ higher risk of nonatopic wheeze, and a SD lower fetal abdominal circumference growth between 19 and 34 weeks of gestation was associated with a $20 \%$ higher risk of atopic wheezing. Another study with retrospectively collected fetal measurements observed that reduced fetal size in first trimester is associated with increased risks for asthma and airway obstruction in children aged 10 years [79]. This study did not take postnatal growth parameters into account. However, infant weight gain, which is generally higher in children with a low birth weight, is also associated with respiratory morbidity in childhood [78, 80]. Recently, a prospective population-based cohort study among 5,125 children observed that not fetal growth, but weight gain acceleration in early infancy was associated with increased risks of asthma symptoms in preschool children, independent of fetal growth [81]. These results suggest that early infancy might be a more critical period for the development of asthma. The associations of longitudinally measured fetal and early childhood growth patterns with various phenotypes of asthma, lung function and lung structure in childhood and later life adjusted for potential confounders remain to be studied in further detail.

In addition to fetal and early childhood growth, preterm birth is suggested to be associated with asthma and impaired lung function [81-88]. A recent meta-analysis showed that preterm birth defined as a gestational age less than 37 weeks at birth was associated with an 1.07-1.36 increased risk of asthma, depending on the heterogeneity of the studies, compared with children born at term [82]. This effect seemed stronger at a younger age but this difference might reflect differences between study populations rather than a real age effect. Potential underlying pathways for the association between preterm birth and asthma are not disentangled yet but might include underdeveloped anatomical or immunological mechanisms [89, 90], interaction with environmental factors, such as smoke exposure and chorioamnionitis [49, 84], or genetic factors [91]. Also, the degree of immaturity, therapeutic interventions and comorbidity might play a role. Recent studies observed inconsistent results on the associations of gestational age and risks of asthma for children born late preterm [85, 87, 
88] and children born early preterm with or without mechanical ventilation [88] or bronchopulmonary dysplasia $[86,92]$. Future studies are needed to elaborate on these aspects.

\section{Maternal smoking and diet}

Maternal smoking is the most important adverse fetal exposure in Western countries, and is strongly associated with fetal growth retardation and low birth weight [63]. Recent studies have demonstrated that maternal smoking during pregnancy is associated with increased risks of wheezing and asthma during childhood [93-99]. Most studies were not able to assess the effect of maternal smoking exposure in different periods of pregnancy, which might be important for identifying critical periods. It is also not known whether the associations between maternal smoking during pregnancy and the risk of childhood asthma are explained by direct intrauterine effects, or reflect other unmeasured environmental confounders. Stronger effect estimates for maternal smoking than for paternal smoking during pregnancy with childhood asthma would suggest direct intra-uterine effects, whereas similar effect estimates suggest that the associations are explained by unmeasured socio-economic, or life style related factors $[100,101]$. Also, as in all observational designs, residual confounding might still be an issue due to unmeasured social and life style related factors. This needs to be explored in detail. Recently, we have demonstrated that continued maternal smoking throughout pregnancy is associated with asthma symptoms, including wheezing, in preschool children [49]. These associations were independent of paternal smoking and imply a direct adverse effect of smoke exposure on fetal lung development. The mechanisms by which maternal smoking during pregnancy affect body and lung growth are not fully understood, but may include direct toxic effects on the respiratory system and DNA methylation of genes. Recent studies showed general and biological pathway specific differences in DNA methylation patterns in children from mothers who smoked during pregnancy [102, 103]. Differences in DNAmethylation within the promoter regions of particular genes may alter the expression of the gene products related to growth and lung development. However, it is not known whether the associations between low birth weight and respiratory disease can be fully explained by fetal smoke exposure, and the related changes in DNA methylation.

Suboptimal fetal nutrition, due to maternal obesity or underweight, insufficient dietary intake, or placental dysfunction might also affect fetal growth and lung development [52, 104-107]. Maternal obesity and placenta dysfunction are strongly related to fetal growth, but their direct associations with respiratory health in the offspring are not fully understood yet $[10,108]$. Insufficient maternal dietary intake of macronutrients during pregnancy may lead to impaired fetal body, lung and airway growth and subsequently to an increased risk of asthma in childhood [104, 109-116]. More specifically, maternal Mediterranean and Western dietary patterns during pregnancy are related to fetal growth patterns $[117,118]$. Thus far, little is known whether these maternal dietary patterns also affect the risk of childhood asthma [119]. The mechanisms by which dietary patterns affect body and lung growth development may also include DNA methylation [120, 121]. Lower intake of micronutrients such as folate, and vitamin B12 in mother's diet may induce epigenetic changes, since folate and vitamin B12 are important methyl donors during pregnancy [122]. Vitamin E has the potential to influence airway development via epigenetic mechanisms because it influences gene expression and airway epithelial cell signalling [112]. The role of epigenetic mechanisms regarding the association of low maternal vitamin $\mathrm{D}$ intake during pregnancy with a higher incidence of asthma and wheeze in children is not known yet [123-127]. The importance of the maternal intake of these micronutrients on respiratory health in childhood and adulthood might differ between developing and Western countries, since the nutritional status of mothers and children in these countries are different.

\section{Exposures in infancy}

After birth, infant diet may also influence body and lung growth development [128]. Specific infant feeding patterns such as early introduction of bottle feeding or solid food instead of a long period of exclusive breastfeeding may lead to reduced lung and airway growth and increased risk of childhood asthma [50, 129-132]. Underlying mechanisms that have been suggested to explain the associations of shorter duration or smaller amount of breastfeeding with the risks of asthma are breast milk components, including IgA, cytokines, glycans and long-chain fatty acids that stimulate and balance the infant's innate immune system and growth [133-135]. Atopic and infectious mechanisms might partly mediate the protective effect of breastfeeding on childhood asthma [50,131, 136, 137]. Thus far, previous studies did report inconsistent results on effect modification by family history of asthma, allergy and atopy on the association of breastfeeding with wheezing [131, 136139]. Also, the protective effect of a longer period of breastfeeding duration on childhood asthma still remains when respiratory tract infections are taken into account [50]. Further studies are needed to explore in detail the role of atopy, infections, suboptimal lung growth [128], 
epigenetic changes [140] and other possible underlying mechanisms in the associations between breastfeeding and asthma.

In the first years, childhood asthma symptoms or wheezing are predominantly related to respiratory tract infections [53, 55, 56, 141, 142]. Respiratory infectious diseases in infancy also predict the risk of asthma and other respiratory diseases in childhood and adulthood [66, 143, 144]. Results from the COPSAC study have shown that colonization of the airways with $S$. pneumoniae, $H$. influenzae, $M$. catarrhalis, or more than one of these organisms in asymptomatic neonates at 1 month of age was associated with increased risks of wheezing symptoms, higher blood eosinophil counts and total IgE, and development of asthma in school age children [56]. Similarly, nasal carriage with $S$. aureus is associated with an increased risk of atopic dermatitis [145]. Still, whether these associations reflect causal mechanisms or reflect symptoms of the same underlying susceptible lung or skin is not known. Acetaminophen is frequently used in children with fever episodes, including those with upper and lower respiratory tract infections. Several studies have suggested associations between acetaminophen in childhood and the risk of asthma [54, 146-150]. A recent review summarized the existing evidence for the associations of acetaminophen use with childhood asthma, and suggested that this association might be causal based on various epidemiological findings including the strength, consistency, and doseresponse relationship [151]. Also, the metabolism of acetaminophen leads to a depletion in airway mucosal glutathione that could contribute to vulnerability to oxidant stress. Prospective studies relating infectious diseases and acetaminophen use with different respiratory health outcomes in adulthood have not been performed yet.

\section{Genetic susceptibility}

The associations of low birth weight with respiratory symptoms in later life might also be explained by common genetic variants leading to both fetal growth restriction and smaller lungs and airways and, subsequently, to asthma. Previous candidate gene studies and linkage studies identified more than 100 genes associated with asthma [152, 153]. However, most of these associations could not be replicated. More recent genome wide approaches in large study populations successfully identified and replicated genetic variants related to asthma in children [154-160]. Variants in the ORM1-like 3 (ORMDL3) gene and in neighbouring genes, such as gasdermin A and B (GSDM), have consistently been associated with risk of childhood asthma. None of the identified common genetic variants related to asthma or COPD were associated with birth weight on a genome wide significant level [161], but this might be due to lack of power. Thus far, no genome wide association studies have been performed on lung function in early childhood. Therefore, further studies are needed that relate genetic variants to both early body and lung growth characteristics and respiratory diseases in later life.

The effects of early life exposures such as maternal smoking and diet, breastfeeding and infant infectious diseases on the risk of asthma and COPD might be modified by a genetic susceptibility. Recent studies suggest that the effects of some genetic variants related to asthma, located on glutathione S-transferase (GST), methylenetetrahydrofolate reductase (MTHFR), gasdermin-like (GSDML) and ORMDL3 genes, are modified by environmental exposures, including tobacco smoke exposure [116, 162-167]. The increased risk of early-onset asthma due to $17 \mathrm{q} 21$ genetic variants of ORDML3, GSDML and 2 other genes was further enhanced by early childhood tobacco smoke exposure $[162,164]$. Also, GST genes in combination with fetal smoke exposure seem to be associated with lower airway responsiveness, lung function and increased risk of transient wheezing, a phenotype of childhood asthma [163, 166]. However, results for effect modification by maternal smoking on the associations of GST genes with respiratory morbidity are not consistent $[167,168]$. Further geneenvironment studies are needed, especially focused on the environmental exposures in the fetal period, during which period alveolar and airway development is largely completed.

\section{Conclusion}

Asthma in childhood is a heterogeneous disease and the exact underlying origins remain partly unknown. Several lines of investigation suggest that asthma has at least part of its origin in fetal life and infancy. Low birth weight seems to be associated with the risk of childhood asthma, but may not be the causal factor per se. Therefore, focus for further research should be beyond birth to identify specific fetal and infant growth patterns, their specific exposures and gene-environment interactions leading to asthma and other respiratory diseases in later life (Fig. 1). Specific early exposures of interest include maternal smoking and diet, infant feeding, and infectious diseases in early life. Developmental adaptation mechanisms in early life that need to be studied in epidemiological study designs include DNA methylation, and detailed imaging and functional assessments of the airways and lungs. Newly identified contributing factors to the origins of respiratory diseases including childhood asthma can ultimately contribute to the development of novel preventive, diagnostic and therapeutic approaches. 


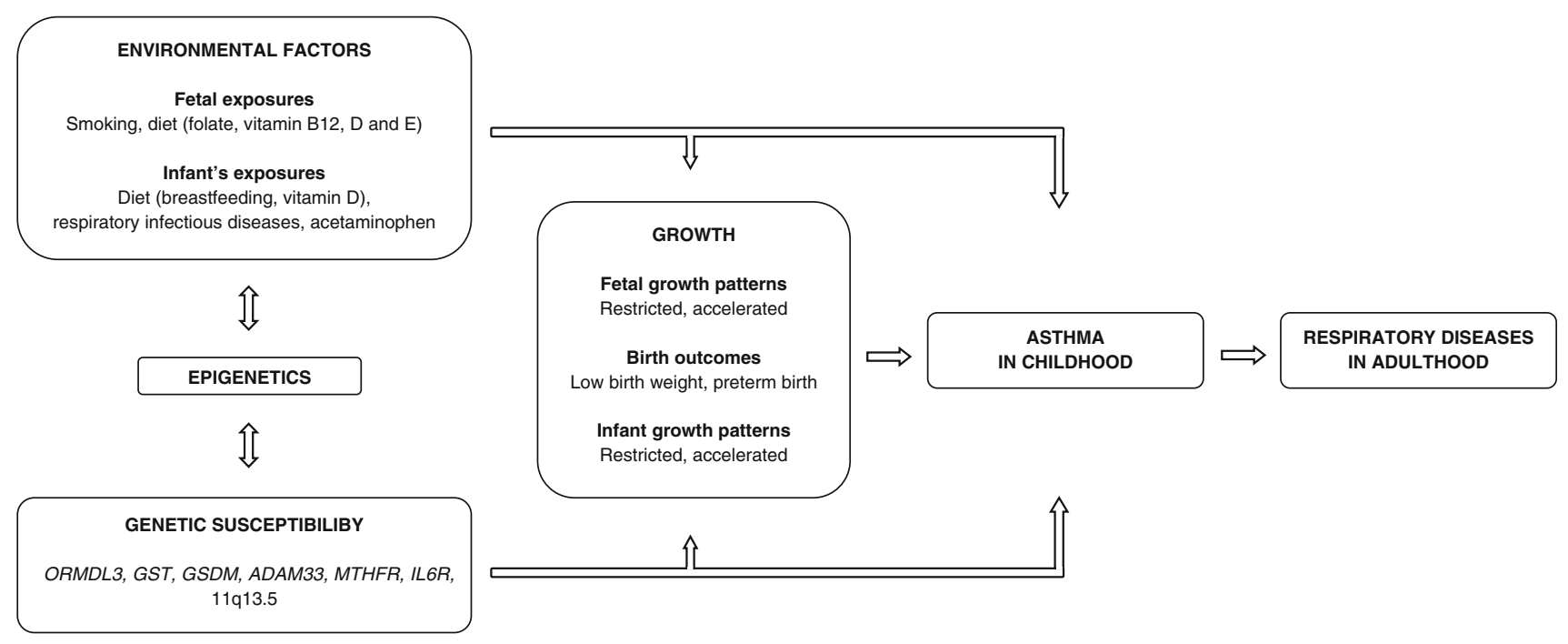

Fig. 1 Pathways leading from adverse fetal and infant exposures to growth adaptations and respiratory health outcomes

Acknowledgments Dr. Liesbeth Duijts received funding by means of a European Respiratory Society/Marie Curie Joint Research Fellowship (nr. MC 1226-2009) under grant agreement RESPIRE, PCOFUND-GA-2008-229571 and from the seventh framework programme, project CHICOS (HEALTH-F2-2009-241504).

Conflict of interest The author has no conflict of interest.

Open Access This article is distributed under the terms of the Creative Commons Attribution License which permits any use, distribution, and reproduction in any medium, provided the original author(s) and the source are credited.

\section{References}

1. Asher MI, Montefort S, Bjorksten B, Lai CK, Strachan DP, Weiland SK, et al. Worldwide time trends in the prevalence of symptoms of asthma, allergic rhinoconjunctivitis, and eczema in childhood: ISAAC phases one and three repeat multicountry cross-sectional surveys. Lancet. 2006;368(9537):733-43.

2. Masoli M, Fabian D, Holt S, Beasley R. The global burden of asthma: executive summary of the GINA Dissemination Committee report. Allergy. 2004;59(5):469-78.

3. Peters SP, Jones CA, Haselkorn T, Mink DR, Valacer DJ, Weiss ST. Real-world evaluation of asthma control and treatment (REACT): findings from a national web-based survey. J Allergy Clin Immunol. 2007;119(6):1454-61.

4. Behrens T. Current trends in aetiological asthma research. Eur J Epidemiol. 2009;24(3):115-8.

5. Reddel HK, Taylor DR, Bateman ED, Boulet LP, Boushey HA, Busse WW, et al. An official American Thoracic Society/European Respiratory Society statement: asthma control and exacerbations: standardizing endpoints for clinical asthma trials and clinical practice. Am J Respir Crit Care Med. 2009;180(1):59-99.

6. Edwards CA, Osman LM, Godden DJ, Douglas JG. Wheezy bronchitis in childhood: a distinct clinical entity with lifelong significance? Chest. 2003;124(1):18-24.

7. Hepworth SJ, Law GR, Lawlor DA, McKinney PA. Early life patterns of common infection: a latent class analysis. Eur $\mathbf{J}$ Epidemiol. 2010;25(12):875-83.
8. Liu G, Zhu H, Dong Y, Podolsky RH, Treiber FA, Snieder H. Influence of common variants in FTO and near INSIG2 and MC4R on growth curves for adiposity in African- and EuropeanAmerican youth. Eur J Epidemiol. 2011;26(6):463-73.

9. Slachtova H, Gehring U, Hoek G, Tomaskova H, LuttmannGibson $\mathrm{H}$, Moshammer $\mathrm{H}$, et al. Parental education and lung function of children in the PATY study. Eur $\mathrm{J}$ Epidemiol. 2011;26(1):45-54.

10. Geelhoed JJ, Jaddoe VW. Early influences on cardiovascular and renal development. Eur J Epidemiol. 2010;25(10):677-92.

11. Waller K, Kujala UM, Rantanen T, Kauppinen M, Silventoinen K, Koskenvuo M, et al. Physical activity, morbidity and mortality in twins: a 24-year prospective follow-up. Eur J Epidemiol. 2010;25(10):731-9.

12. Alatupa S, Pulkki-Raback L, Hintsanen M, Ravaja N, Raitakari OT, Telama R, et al. School performance as a predictor of adulthood obesity: a 21-year follow-up study. Eur J Epidemiol. 2010;25(4):267-74.

13. Engeland A, Bjorge T, Daltveit AK, Skurtveit S, Vangen S, Vollset SE, et al. Risk of diabetes after gestational diabetes and preeclampsia. A registry-based study of 230,000 women in Norway. Eur J Epidemiol. 2011;26(2):157-63.

14. Durmus B, Ay L, Hokken-Koelega AC, Raat H, Hofman A, Steegers EA, et al. Maternal smoking during pregnancy and subcutaneous fat mass in early childhood. The Generation R Study. Eur J Epidemiol. 2011;26(4):295-304.

15. Beyerlein A, Ruckinger S, Toschke AM. Schaffrath Rosario A, von Kries R. Is low birth weight in the causal pathway of the association between maternal smoking in pregnancy and higher BMI in the offspring? Eur J Epidemiol. 2011;26(5):413-20.

16. Pedersen GS, Mortensen LH, Andersen AM. Ethnic variations in mortality in pre-school children in Denmark, 1973-2004. Eur J Epidemiol. 2011;26(7):527-36.

17. Rours GI, Duijts L, Moll HA, Arends LR, de Groot R, Jaddoe VW, et al. Chlamydia trachomatis infection during pregnancy associated with preterm delivery: a population-based prospective cohort study. Eur J Epidemiol. 2011;26(6):493-502.

18. Cnattingius S, Svensson T, Granath F, Iliadou A. Maternal smoking during pregnancy and risks of suicidal acts in young offspring. Eur J Epidemiol. 2011;26(6):485-92.

19. Labout JA, Duijts L, Lebon A, de Groot R, Hofman A, Jaddoe VV, et al. Risk factors for otitis media in children with special emphasis 
on the role of colonization with bacterial airway pathogens: the Generation R Study. Eur J Epidemiol. 2011;26(1): 61-6.

20. Morseth B, Emaus N, Wilsgaard T, Jacobsen BK, Jorgensen L. Leisure time physical activity in adulthood is positively associated with bone mineral density 22 years later. The Tromso study. Eur J Epidemiol. 2010;25(5):325-31.

21. Greenwood DC, Alwan N, Boylan S, Cade JE, Charvill J, Chipps KC, et al. Caffeine intake during pregnancy, late miscarriage and stillbirth. Eur J Epidemiol. 2010;25(4):275-80.

22. Ghasemi A, Zahediasl S, Azizi F. Nitric oxide and clustering of metabolic syndrome components in pediatrics. Eur J Epidemiol. 2010;25(1):45-53.

23. Strand BH, Cooper R, Hardy R, Kuh D, Guralnik J. Lifelong socioeconomic position and physical performance in midlife: results from the British 1946 birth cohort. Eur J Epidemiol. 2011;26(6):475-83.

24. Timmermans S, Bonsel GJ, Steegers-Theunissen RP, Mackenbach JP, Steyerberg EW, Raat H, et al. Individual accumulation of heterogeneous risks explains perinatal inequalities within deprived neighbourhoods. Eur J Epidemiol. 2011;26(2):165-80.

25. Borne Y, Engstrom G, Essen B, Sundquist J, Hedblad B. Country of birth and risk of hospitalization due to heart failure: a Swedish population-based cohort study. Eur J Epidemiol. 2011;26(4):275-83.

26. Lagiou P, Samoli E, Lipworth L, Lagiou A, Fang F, Rossi M, et al. Energy intake during pregnancy in relation to offspring gender by maternal height. Eur J Epidemiol. 2011;26(1):39-44.

27. Gudmundsson P, Andersson S, Gustafson D, Waern M, Ostling $\mathrm{S}$, Hallstrom T, et al. Depression in Swedish women: relationship to factors at birth. Eur J Epidemiol. 2011;26(1):55-60.

28. Ngo AD, Taylor R, Roberts CL. Paternal exposure to Agent Orange and spina bifida: a meta-analysis. Eur J Epidemiol. 2010;25(1):37-44.

29. Both MI, Overvest MA, Wildhagen MF, Golding J, Wildschut HI. The association of daily physical activity and birth outcome: a population-based cohort study. Eur J Epidemiol. 2010; 25(6):421-9.

30. Heys M, Jiang C, Schooling CM, Zhang W, Cheng KK, Lam $\mathrm{TH}$, et al. Is childhood meat eating associated with better later adulthood cognition in a developing population? Eur J Epidemiol. 2010;25(7):507-16.

31. Sellier E, Surman G, Himmelmann K, Andersen G, Colver A, Krageloh-Mann I, et al. Trends in prevalence of cerebral palsy in children born with a birthweight of 2,500 g or over in Europe from 1980 to 1998. Eur J Epidemiol. 2010;25(9):635-42.

32. Huisman M, Araya R, Lawlor DA, Ormel J, Verhulst FC, Oldehinkel AJ. Cognitive ability, parental socioeconomic position and internalising and externalising problems in adolescence: findings from two European cohort studies. Eur J Epidemiol. 2010;25(8):569-80.

33. Reuser M, Willekens FJ, Bonneux L. Higher education delays and shortens cognitive impairment: a multistate life table analysis of the US Health and Retirement Study. Eur J Epidemiol. 2011;26(5):395-403.

34. Rours GI, de Krijger RR, Ott A, Willemse HF, de Groot R, Zimmermann LJ, et al. Chlamydia trachomatis and placental inflammation in early preterm delivery. Eur $\mathrm{J}$ Epidemiol. 2011;26(5):421-8.

35. Castello A, Rio I, Sandin-Vazquez M, Bolumar F. Shortening of gestational length among native-born and immigrants in Spain (1997-2008). Eur J Epidemiol. 2011;26(7):563-70.

36. Danziger PD, Silverwood R, Koupil I. Fetal growth, early life circumstances, and risk of suicide in late adulthood. Eur J Epidemiol. 2011;26(7):571-81.
37. Diouf I, Charles MA, Thiebaugeorges O, Forhan A, Kaminski M, Heude B. Maternal weight change before pregnancy in relation to birthweight and risks of adverse pregnancy outcomes. Eur J Epidemiol. 2011;26(10):789-96.

38. Bakker H, Jaddoe VW. Cardiovascular and metabolic influences of fetal smoke exposure. Eur J Epidemiol. 2011;26(10):763-70.

39. Tamakoshi K, Yatsuya H, Tamakoshi A. Early age at menarche associated with increased all-cause mortality. Eur J Epidemiol. 2011;26(10):771-8.

40. Johnson PC, Logue J, McConnachie A, Abu-Rmeileh NM, Hart $\mathrm{C}$, Upton $\mathrm{MN}$, et al. Intergenerational change and familial aggregation of body mass index. Eur J Epidemiol. 2011. doi: 10.1007/s10654-011-9639-5.

41. Gaillard R, de Ridder MA, Verburg BO, Witteman JC, Mackenbach JP, Moll HA, et al. Individually customised fetal weight charts derived from ultrasound measurements: the Generation $\mathrm{R}$ Study. Eur J Epidemiol. 2011;26(12):919-26.

42. Martinez FD, Wright AL, Taussig LM, Holberg CJ, Halonen M, Morgan WJ. Asthma and wheezing in the first six years of life. The Group Health Medical Associates. N Engl J Med. 1995;332(3):133-8.

43. Horak E, Lanigan A, Roberts M, Welsh L, Wilson J, Carlin JB, et al. Longitudinal study of childhood wheezy bronchitis and asthma: outcome at age 42. BMJ. 2003;326(7386):422-3.

44. Sears MR, Greene JM, Willan AR, Wiecek EM, Taylor DR, Flannery EM, et al. A longitudinal, population-based, cohort study of childhood asthma followed to adulthood. N Engl J Med. 2003;349(15):1414-22.

45. Illi S, von Mutius E, Lau S, Niggemann B, Gruber C, Wahn U, et al. Perennial allergen sensitisation early in life and chronic asthma in children: a birth cohort study. Lancet. 2006;368(9537): 763-70.

46. Haland G, Carlsen KC, Sandvik L, Devulapalli CS, MuntheKaas MC, Pettersen M, et al. Reduced lung function at birth and the risk of asthma at 10 years of age. $\mathrm{N}$ Engl $\mathrm{J}$ Med. 2006;355(16):1682-9.

47. Stern DA, Morgan WJ, Wright AL, Guerra S, Martinez FD. Poor airway function in early infancy and lung function by age 22 years: a non-selective longitudinal cohort study. Lancet. 2007;370(9589):758-64.

48. Stern DA, Morgan WJ, Halonen M, Wright AL, Martinez FD. Wheezing and bronchial hyper-responsiveness in early childhood as predictors of newly diagnosed asthma in early adulthood: a longitudinal birth-cohort study. Lancet. 2008;372(9643): 1058-64.

49. Duijts L, Jaddoe VW, van der Valk RJ, Henderson AJ, Hofman A, Raat H, Steegers EA, Moll HA, de Jongste JC. Fetal exposure to maternal and paternal smoking and the risks of wheezing in preschool children. The Generation R Study. Chest. 2011. doi: 10.1378/chest.11-0112.

50. Sonnenschein-van der Voort AM, Jaddoe VV, van der Valk RJ, Willemsen SP, Hofman A, Moll HA, et al. Duration and exclusiveness of breastfeeding and childhood asthma-related symptoms. Eur Respir J. 2012;39(1):81-9.

51. von Mutius E. Environmental factors influencing the development and progression of pediatric asthma. J Allergy Clin Immunol. 2002;109(6 Suppl):S525-32.

52. Lowe A, Braback L, Ekeus C, Hjern A, Forsberg B. Maternal obesity during pregnancy as a risk for early-life asthma. J Allergy Clin Immunol. 2011;128(5):1107-9. e1-2.

53. Ege MJ, Mayer M, Normand AC, Genuneit J, Cookson WO, BraunFahrlander C, et al. Exposure to environmental microorganisms and childhood asthma. N Engl J Med. 2011;364(8):701-9.

54. Beasley RW, Clayton TO, Crane J, Lai CK, Montefort SR, Mutius E, et al. Acetaminophen use and risk of asthma, 
rhinoconjunctivitis, and eczema in adolescents: International Study of Asthma and Allergies in Childhood phase three. Am J Respir Crit Care Med. 2011;183(2):171-8.

55. Bisgaard H, Hermansen MN, Bonnelykke K, Stokholm J, Baty F, Skytt NL, et al. Association of bacteria and viruses with wheezy episodes in young children: prospective birth cohort study. BMJ. 2010;341:c4978.

56. Bisgaard H, Hermansen MN, Buchvald F, Loland L, Halkjaer LB, Bonnelykke K, et al. Childhood asthma after bacterial colonization of the airway in neonates. $N$ Engl $J$ Med. 2007;357(15):1487-95.

57. Barker DJ. The intrauterine origins of cardiovascular and obstructive lung disease in adult life. The Marc Daniels lecture 1990. J R Coll Physicians Lond. 1991;25(2):129-33.

58. Canoy D, Pekkanen J, Elliott P, Pouta A, Laitinen J, Hartikainen $\mathrm{AL}$, et al. Early growth and adult respiratory function in men and women followed from the fetal period to adulthood. Thorax. 2007;62(5):396-402.

59. Tennant PW, Gibson GJ, Parker L, Pearce MS. Childhood respiratory illness and lung function at ages 14 and 50 years: childhood respiratory illness and lung function. Chest. 2010;137(1):146-55.

60. Hancox RJ, Poulton R, Greene JM, McLachlan CR, Pearce MS, Sears MR. Associations between birth weight, early childhood weight gain and adult lung function. Thorax. 2009;64(3):228-32.

61. Lawlor DA, Ebrahim S, Davey Smith V. Association of birth weight with adult lung function: findings from the British Women's Heart and Health Study and a meta-analysis. Thorax. 2005;60(10):851-8.

62. Caudri D, Wijga A, Gehring U, Smit HA, Brunekreef B, Kerkhof M, et al. Respiratory symptoms in the first 7 years of life and birth weight at term: the PIAMA Birth Cohort. Am J Respir Crit Care Med. 2007;175(10):1078-85.

63. Jaddoe VW, Verburg BO, de Ridder MA, Hofman A, Mackenbach JP, Moll HA, et al. Maternal smoking and fetal growth characteristics in different periods of pregnancy: the Generation R study. Am J Epidemiol. 2007;165(10):1207-15.

64. Gluckman PD, Hanson MA, Cooper C, Thornburg KL. Effect of in utero and early-life conditions on adult health and disease. N Engl J Med. 2008;359(1):61-73.

65. Osler M, Lund R, Kriegbaum M, Andersen AM. The influence of birth weight and body mass in early adulthood on early coronary heart disease risk among Danish men born in 1953. Eur J Epidemiol. 2009;24(1):57-61.

66. Barker DJ, Godfrey KM, Fall C, Osmond C, Winter PD, Shaheen SO. Relation of birth weight and childhood respiratory infection to adult lung function and death from chronic obstructive airways disease. BMJ. 1991;303(6804):671-5.

67. Shi W, Bellusci S, Warburton D. Lung development and adult lung diseases. Chest. 2007;132(2):651-6.

68. Aysola RS, Hoffman EA, Gierada D, Wenzel S, Cook-Granroth $\mathrm{J}$, Tarsi J, et al. Airway remodeling measured by multidetector $\mathrm{CT}$ is increased in severe asthma and correlates with pathology. Chest. 2008;134(6):1183-91.

69. Castagnaro A, Rastelli A, Chetta A, Marangio E, Tzani P, De Filippo M, et al. High-resolution computed tomography evaluation of airway distensibility in asthmatic and healthy subjects. Radiol Med. 2008;113(1):43-55.

70. Grainge CL, Lau LC, Ward JA, Dulay V, Lahiff G, Wilson S, et al. Effect of bronchoconstriction on airway remodeling in asthma. N Engl J Med. 2011;364(21):2006-15.

71. van der Gugten A, Korte K, van der Ent K, Uiterwaal C, Verheij T. Small airway caliber is the most important contributor of wheezing in healthy unselected newborns. Am J Respir Crit Care Med. 2011;183(4):553. (Author reply-4).
72. van Oosterhout AJ, Bloksma N. Regulatory T-lymphocytes in asthma. Eur Respir J. 2005;26(5):918-32.

73. Tang ML, Kemp AS, Thorburn J, Hill DJ. Reduced interferongamma secretion in neonates and subsequent atopy. Lancet. 1994;344(8928):983-5.

74. Sly PD, Holt PG. Role of innate immunity in the development of allergy and asthma. Curr Opin Allergy Clin Immunol. 2011;11(2):127-31.

75. Gimeno D, Delclos GL, Ferrie JE, De Vogli R, Elovainio M, Marmot MG, et al. Association of CRP and IL-6 with lung function in a middle-aged population initially free from selfreported respiratory problems: the Whitehall II study. Eur J Epidemiol. 2011;26(2):135-44.

76. Inskip HM, Godfrey KM, Robinson SM, Law CM, Barker DJ, Cooper C, et al. Cohort profile: the Southampton women's survey. Int J Epidemiol. 2006;35(1):42-8.

77. Jaddoe VW, van Duijn CM, van der Heijden AJ, Mackenbach JP, Moll HA, Steegers EA, et al. The Generation R Study: design and cohort update 2010. Eur J Epidemiol. 2010;25(11):823-41.

78. Pike KC, Crozier SR, Lucas JS, Inskip HM, Robinson S, Roberts $\mathrm{G}$, et al. Patterns of fetal and infant growth are related to atopy and wheezing disorders at age 3 years. Thorax. 2010;65(12): 1099-106.

79. Turner S, Prabhu N, Danielan P, McNeill G, Craig L, Allan C, et al. First- and second-trimester fetal size and asthma outcomes at age 10 years. Am J Respir Crit Care Med. 2011;184(4):407-13.

80. van der Gugten AC, Koopman M, Evelein AM, Verheij TJ, Uiterwaal CS, van der Ent CK. Rapid early weight gain is associated with wheeze and reduced lung function in childhood. Eur Respir J. 2012;39(2):403-10.

81. Sonnenschein-van der Voort AM, Jaddoe VW, Raat H, Moll HA, Hofman A, de Jongste JC, et al. Fetal and Infant Growth and Asthma Symptoms in Preschool Children. The Generation R Study. Am J Respir Crit Care Med. 2012. doi:10.1164/rccm. 201107-1266OC.

82. Jaakkola JJ, Ahmed P, Ieromnimon A, Goepfert P, Laiou E, Quansah R, et al. Preterm delivery and asthma: a systematic review and meta-analysis. J Allergy Clin Immunol. 2006;118(4): 823-30.

83. Gessner BD, Chimonas MA. Asthma is associated with preterm birth but not with small for gestational age status among a population-based cohort of Medicaid-enrolled children $<10$ years of age. Thorax. 2007;62(3):231-6.

84. Kumar R, Yu Y, Story RE, Pongracic JA, Gupta R, Pearson C, et al. Prematurity, chorioamnionitis, and the development of recurrent wheezing: a prospective birth cohort study. J Allergy Clin Immunol. 2008;121(4):878-84. (e6).

85. Abe K, Shapiro-Mendoza CK, Hall LR, Satten GA. Late preterm birth and risk of developing asthma. J Pediatr. 2010;157(1): $74-8$.

86. Fawke J, Lum S, Kirkby J, Hennessy E, Marlow N, Rowell V, et al. Lung function and respiratory symptoms at 11 years in children born extremely preterm: the EPICure study. Am J Respir Crit Care Med. 2010;182(2):237-45.

87. Crump C, Winkleby MA, Sundquist J, Sundquist K. Risk of asthma in young adults who were born preterm: a Swedish national cohort study. Pediatrics. 2011;127(4):e913-20.

88. Kotecha SJ, Watkins WJ, Paranjothy S, Dunstan FD, Henderson AJ, Kotecha S. Effect of late preterm birth on longitudinal lung spirometry in school age children and adolescents. Thorax. 2012;67(1):54-61.

89. Siltanen M, Wehkalampi K, Hovi P, Eriksson JG, Strang-Kar1sson S, Jarvenpaa AL, et al. Preterm birth reduces the incidence of atopy in adulthood. J Allergy Clin Immunol. 2011;127(4): 935-42. 
90. Broughton S, Thomas MR, Marston L, Calvert SA, Marlow N, Peacock JL, et al. Very prematurely born infants wheezing at follow-up: lung function and risk factors. Arch Dis Child. 2007;92(9):776-80.

91. Hallman M, Marttila R, Pertile R, Ojaniemi M, Haataja R. Genes and environment in common neonatal lung disease. Neonatology. 2007;91(4):298-302.

92. Baraldi E, Filippone M. Chronic lung disease after premature birth. N Engl J Med. 2007;357(19):1946-55.

93. Lux AL, Henderson AJ, Pocock SJ. Wheeze associated with prenatal tobacco smoke exposure: a prospective, longitudinal study. ALSPAC study team. Arch Dis Child. 2000;83(4): 307-12.

94. Haberg SE, Stigum H, Nystad W, Nafstad P. Effects of pre- and postnatal exposure to parental smoking on early childhood respiratory health. Am J Epidemiol. 2007;166(6):679-86.

95. Lannero E, Wickman M, Pershagen G, Nordvall L. Maternal smoking during pregnancy increases the risk of recurrent wheezing during the first years of life (BAMSE). Respir Res. 2006;7:3

96. Magnusson LL, Olesen AB, Wennborg H, Olsen J. Wheezing, asthma, hayfever, and atopic eczema in childhood following exposure to tobacco smoke in fetal life. Clin Exp Allergy. 2005;35(12):1550-6.

97. Gilliland FD, Berhane K, Li YF, Rappaport EB, Peters JM. Effects of early onset asthma and in utero exposure to maternal smoking on childhood lung function. Am J Respir Crit Care Med. 2003;167(6):917-24.

98. Stein RT, Holberg CJ, Sherrill D, Wright AL, Morgan WJ, Taussig L, et al. Influence of parental smoking on respiratory symptoms during the first decade of life: the Tucson Children's Respiratory Study. Am J Epidemiol. 1999;149(11):1030-7.

99. Prabhu N, Smith N, Campbell D, Craig LC, Seaton A, Helms PJ, et al. First trimester maternal tobacco smoking habits and fetal growth. Thorax. 2010;65(3):235-40.

100. Davey Smith G, Leary S, Ness A, Lawlor DA. Challenges and novel approaches in the epidemiological study of early life influences on later disease. Adv Exp Med Biol. 2009;646:1-14.

101. Brion MJ, Leary SD, Smith GD, Ness AR. Similar associations of parental prenatal smoking suggest child blood pressure is not influenced by intrauterine effects. Hypertension. 2007;49(6): 1422-8.

102. Breton CV, Byun HM, Wang X, Salam MT, Siegmund K, Gilliland FD. DNA methylation in the arginase-nitric oxide synthase pathway is associated with exhaled nitric oxide in children with asthma. Am J Respir Crit Care Med. 2011;184(2): 191-7.

103. Breton CV, Byun HM, Wenten M, Pan F, Yang A, Gilliland FD. Prenatal tobacco smoke exposure affects global and gene-specific DNA methylation. Am J Respir Crit Care Med. 2009;180(5): 462-7.

104. Patel SP, Rodriguez A, Little MP, Elliott P, Pekkanen J, Hartikainen AL, et al. Associations between pre-pregnancy obesity and asthma symptoms in adolescents. J Epidemiol Commun Health. 2011. doi:10.1136/jech.2011.133777.

105. Lopuhaa CE, Roseboom TJ, Osmond C, Barker DJ, Ravelli AC, Bleker OP, et al. Atopy, lung function, and obstructive airways disease after prenatal exposure to famine. Thorax. 2000;55(7):555-61.

106. Schachter LM, Salome CM, Peat JK, Woolcock AJ. Obesity is a risk for asthma and wheeze but not airway hyperresponsiveness. Thorax. 2001;56(1):4-8.

107. Lowe A, Braback L, Ekeus C, Hjern A, Forsberg B. Maternal obesity during pregnancy as a risk for early-life asthma. J Allergy Clin Immunol. 2011;128(5):1107-9. (e1-e2).

108. Ay L, Kruithof CJ, Bakker R, Steegers EA, Witteman JC, Moll $\mathrm{HA}$, et al. Maternal anthropometrics are associated with fetal size in different periods of pregnancy and at birth. The Generation R Study. BJOG. 2009;116(7):953-63.

109. Shaheen SO. Prenatal nutrition and asthma: hope or hype? Thorax. 2008;63(6):483-5.

110. Whitrow MJ, Moore VM, Rumbold AR, Davies MJ. Effect of supplemental folic acid in pregnancy on childhood asthma: a prospective birth cohort study. Am J Epidemiol. 2009;170(12): 1486-93.

111. Haberg SE, London SJ, Stigum H, Nafstad P, Nystad W. Folic acid supplements in pregnancy and early childhood respiratory health. Arch Dis Child. 2009;94(3):180-4.

112. Turner SW, Campbell D, Smith N, Craig LC, McNeill G, Forbes $\mathrm{SH}$, et al. Associations between fetal size, maternal \{alpha\}tocopherol and childhood asthma. Thorax. 2010;65(5):391-7.

113. Shaheen SO, Northstone K, Newson RB, Emmett PM, Sherriff A, Henderson AJ. Dietary patterns in pregnancy and respiratory and atopic outcomes in childhood. Thorax. 2009;64(5):411-7.

114. Scholtens S, Wijga AH, Brunekreef B, Kerkhof M, Postma DS, Oldenwening $\mathrm{M}$, et al. Maternal overweight before pregnancy and asthma in offspring followed for 8 years. Int $\mathrm{J}$ Obes (Lond). 2010;34(4):606-13.

115. Nagel G, Weinmayr G, Kleiner A, Garcia-Marcos L, Strachan DP. Effect of diet on asthma and allergic sensitisation in the International Study on Allergies and Asthma in Childhood (ISAAC) phase two. Thorax. 2010;65(6):516-22.

116. Granell R, Heron J, Lewis S, Davey Smith G, Sterne JA, Henderson J. The association between mother and child MTHFR C677T polymorphisms, dietary folate intake and childhood atopy in a population-based, longitudinal birth cohort. Clin Exp Allergy. 2008;38(2):320-8.

117. Heppe DH, Steegers EA, Timmermans S, Breeijen H, Tiemeier $\mathrm{H}$, Hofman A, et al. Maternal fish consumption, fetal growth and the risks of neonatal complications: the Generation R Study. Br J Nutr. 2011;105(6):938-49.

118. Stein AD, Ravelli AC, Lumey LH. Famine, third-trimester pregnancy weight gain, and intrauterine growth: the Dutch Famine Birth Cohort Study. Hum Biol. 1995;67(1):135-50.

119. Miyake Y, Okubo H, Sasaki S, Tanaka K, Hirota Y. Maternal dietary patterns during pregnancy and risk of wheeze and eczema in Japanese infants aged 16-24 months: the Osaka Maternal and Child Health Study. Pediatr Allergy Immunol. 2011;22(7):734-41.

120. Heijmans BT, Tobi EW, Stein AD, Putter H, Blauw GJ, Susser ES, et al. Persistent epigenetic differences associated with prenatal exposure to famine in humans. Proc Natl Acad Sci USA. 2008;105(44):17046-9.

121. Tobi EW, Heijmans BT, Kremer D, Putter H, Delemarre-van de Waal HA, Finken MJ, et al. DNA methylation of IGF2, GNASAS, INSIGF and LEP and being born small for gestational age. Epigenetics. 2011;6(2):171-6.

122. Steegers-Theunissen RP, Obermann-Borst SA, Kremer D, Lindemans J, Siebel C, Steegers EA, et al. Periconceptional maternal folic acid use of 400 microg per day is related to increased methylation of the IGF2 gene in the very young child. PLoS One. 2009;4(11):e7845.

123. Camargo CA Jr, Rifas-Shiman SL, Litonjua AA, Rich-Edwards JW, Weiss ST, Gold DR, et al. Maternal intake of vitamin D during pregnancy and risk of recurrent wheeze in children at $3 \mathrm{y}$ of age. Am J Clin Nutr. 2007;85(3):788-95.

124. Devereux G, Litonjua AA, Turner SW, Craig LC, McNeill G, Martindale S, et al. Maternal vitamin D intake during pregnancy and early childhood wheezing. Am J Clin Nutr. 2007;85(3):853-9.

125. Miyake Y, Sasaki S, Tanaka K, Hirota Y. Maternal B vitamin intake during pregnancy and wheeze and eczema in Japanese infants aged 16-24 months: the Osaka Maternal and Child Health Study. Pediatr Allergy Immunol. 2011;22(1 Pt 1):69-74. 
126. Erkkola M, Kaila M, Nwaru BI, Kronberg-Kippila C, Ahonen S, Nevalainen J, et al. Maternal vitamin D intake during pregnancy is inversely associated with asthma and allergic rhinitis in 5-year-old children. Clin Exp Allergy. 2009;39(6):875-82.

127. Sundar IK, Rahman I. Vitamin d and susceptibility of chronic lung diseases: role of epigenetics. Front Pharmacol. 2011;2:50.

128. Durmus B, van Rossem L, Duijts L, Arends LR, Raat H, Moll HA, et al. Breast-feeding and growth in children until the age of 3 years: the Generation R Study. Br J Nutr. 2011;105(11):1704-11.

129. Kramer MS, Matush L, Vanilovich I, Platt R, Bogdanovich N, Sevkovskaya Z, et al. Effect of prolonged and exclusive breast feeding on risk of allergy and asthma: cluster randomised trial. BMJ. 2007 Oct 20;335(7624):815.

130. Sears MR, Greene JM, Willan AR, Taylor DR, Flannery EM, Cowan JO, et al. Long-term relation between breastfeeding and development of atopy and asthma in children and young adults: a longitudinal study. Lancet. 2002;360(9337):901-7.

131. Elliott L, Henderson J, Northstone K, Chiu GY, Dunson D, London SJ. Prospective study of breast-feeding in relation to wheeze, atopy, and bronchial hyperresponsiveness in the Avon Longitudinal Study of Parents and Children (ALSPAC). J Allergy Clin Immunol. 2008;122(1):49-54. (e1-e3).

132. Fisk CM, Crozier SR, Inskip HM, Godfrey KM, Cooper C, Roberts GC, et al. Breastfeeding and reported morbidity during infancy: findings from the Southampton Women's Survey. Matern Child Nutr. 2011;7(1):61-70.

133. Friedman NJ, Zeiger RS. The role of breast-feeding in the development of allergies and asthma. J Allergy Clin Immunol. 2005;115(6): 1238-48.

134. Newburg DS. Neonatal protection by an innate immune system of human milk consisting of oligosaccharides and glycans. J Anim Sci. 2009;87(13 Suppl):26-34.

135. Hoppu U, Kalliomaki M, Laiho K, Isolauri E. Breast milkimmunomodulatory signals against allergic diseases. Allergy. 2001;56(Suppl 67):23-6.

136. Scholtens S, Wijga AH, Brunekreef B, Kerkhof M, Hoekstra $\mathrm{MO}$, Gerritsen J, et al. Breast feeding, parental allergy and asthma in children followed for 8 years. The PIAMA birth cohort study. Thorax. 2009;64(7):604-9.

137. Rothenbacher D, Weyermann M, Beermann C, Brenner H. Breastfeeding, soluble CD14 concentration in breast milk and risk of atopic dermatitis and asthma in early childhood: birth cohort study. Clin Exp Allergy. 2005;35(8):1014-21.

138. Wright AL, Holberg CJ, Taussig LM, Martinez FD. Factors influencing the relation of infant feeding to asthma and recurrent wheeze in childhood. Thorax. 2001;56(3):192-7.

139. Ball TM, Castro-Rodriguez JA, Griffith KA, Holberg CJ, Martinez FD, Wright AL. Siblings, day-care attendance, and the risk of asthma and wheezing during childhood. $\mathrm{N}$ Engl $\mathrm{J}$ Med. 2000;343(8):538-43.

140. Mook-Kanamori DO, Steegers EA, Uitterlinden AG, Moll HA, van Duijn CM, Hofman A, et al. Breast-feeding modifies the association of PPARgamma2 polymorphism Pro12Ala with growth in early life: the Generation R Study. Diabetes. 2009; 58(4):992-8.

141. Riedler J, Braun-Fahrlander C, Eder W, Schreuer M, Waser M, Maisch S, et al. Exposure to farming in early life and development of asthma and allergy: a cross-sectional survey. Lancet. 2001;358(9288):1129-33.

142. Friedlander SL, Jackson DJ, Gangnon RE, Evans MD, Li Z, Roberg KA, et al. Viral infections, cytokine dysregulation and the origins of childhood asthma and allergic diseases. Pediatr Infect Dis J. 2005;24(11 Suppl):S170-6. (discussion S4-S5).

143. Shaheen SO, Barker DJ, Holgate ST. Do lower respiratory tract infections in early childhood cause chronic obstructive pulmonary disease? Am J Respir Crit Care Med. 1995;151(5): 1649-51. (discussion 51-52).

144. Schnabel E, Heinrich J, Group LS. Respiratory tract infections and not paracetamol medication during infancy are associated with asthma development in childhood. J Allergy Clin Immunol. 2010;126(5):1071-3.

145. Lebon A, Labout JA, Verbrugh HA, Jaddoe VW, Hofman A, van Wamel WJ, et al. Role of Staphylococcus aureus nasal colonization in atopic dermatitis in infants: the Generation $\mathrm{R}$ Study. Arch Pediatr Adolesc Med. 2009;163(8):745-9.

146. Lowe AJ, Carlin JB, Bennett CM, Hosking CS, Allen KJ, Robertson CF, et al. Paracetamol use in early life and asthma: prospective birth cohort study. BMJ. 2010;341:c4616.

147. Shaheen SO, Newson RB, Ring SM, Rose-Zerilli MJ, Holloway JW, Henderson AJ. Prenatal and infant acetaminophen exposure, antioxidant gene polymorphisms, and childhood asthma. J Allergy Clin Immunol. 2010;126(6):1141-8. (e7).

148. Shaheen SO, Newson RB, Sherriff A, Henderson AJ, Heron JE, Burney PG, et al. Paracetamol use in pregnancy and wheezing in early childhood. Thorax. 2002;57(11):958-63.

149. Shaheen SO, Newson RB, Henderson AJ, Headley JE, Stratton FD, Jones RW, et al. Prenatal paracetamol exposure and risk of asthma and elevated immunoglobulin $\mathrm{E}$ in childhood. Clin Exp Allergy. 2005;35(1):18-25.

150. Shaheen SO, Newson RB, Smith GD, Henderson AJ. Prenatal paracetamol exposure and asthma: further evidence against confounding. Int J Epidemiol. 2010;39(3):790-4.

151. McBride JT. The association of acetaminophen and asthma prevalence and severity. Pediatrics. 2011;128(6):1181-5.

152. Ober C, Hoffjan S. Asthma genetics 2006: the long and winding road to gene discovery. Genes Immun. 2006;7(2):95-100.

153. Hall IP, Blakey JD, Al Balushi KA, Wheatley A, Sayers I, Pembrey ME, et al. Beta2-adrenoceptor polymorphisms and asthma from childhood to middle age in the British 1958 birth cohort: a genetic association study. Lancet. 2006;368(9537): 771-9.

154. Noguchi E, Sakamoto H, Hirota T, Ochiai K, Imoto Y, Sakashita $\mathrm{M}$, et al. Genome-Wide Association Study identifies HLA-DP as a susceptibility gene for pediatric asthma in Asian populations. PLoS Genet. 2011;7(7):e1002170.

155. Hancock DB, Romieu I, Shi M, Sienra-Monge JJ, Wu H, Chiu $\mathrm{GY}$, et al. Genome-wide association study implicates chromosome 9q21.31 as a susceptibility locus for asthma in mexican children. PLoS Genet. 2009;5(8):e1000623.

156. Mexico City Childhood Asthma S, Torgerson DG, Ampleford EJ, Chiu GY, Gauderman WJ, Gignoux CR, et al. Meta-analysis of genome-wide association studies of asthma in ethnically diverse North American populations. Nat Genet. 2011;43(9): 887-92.

157. Hirota T, Takahashi A, Kubo M, Tsunoda T, Tomita K, Doi S, et al. Genome-wide association study identifies three new susceptibility loci for adult asthma in the Japanese population. Nat Genet. 2011;43(9):893-6.

158. Moffatt MF, Gut IG, Demenais F, Strachan DP, Bouzigon E, Heath S, et al. A large-scale, consortium-based genomewide association study of asthma. N Engl J Med. 2010;363(13): 1211-21.

159. Sleiman PM, Flory J, Imielinski M, Bradfield JP, Annaiah K, Willis-Owen SA, et al. Variants of DENND1B associated with asthma in children. N Engl J Med. 2010;362(1):36-44.

160. Ferreira MA, Matheson MC, Duffy DL, Marks GB, Hui J, Le Souef P, et al. Identification of IL6R and chromosome 11q13.5 as risk loci for asthma. Lancet. 2011;378(9795):1006-14.

161. Freathy RM, Mook-Kanamori DO, Sovio U, Prokopenko I, Timpson NJ, Berry DJ, et al. Variants in ADCY5 and near 
CCNL1 are associated with fetal growth and birth weight. Nat Genet. 2010;42(5):430-5.

162. Bouzigon E, Corda E, Aschard H, Dizier MH, Boland A, Bousquet J, et al. Effect of 17q21 variants and smoking exposure in early-onset asthma. N Engl J Med. 2008;359(19):1985-94.

163. Murdzoska J, Devadason SG, Khoo SK, Landau LI, Young S, Goldblatt $\mathrm{J}$, et al. In utero smoke exposure and role of maternal and infant glutathione s-transferase genes on airway responsiveness and lung function in infancy. Am J Respir Crit Care Med. 2010;181(1):64-71.

164. Flory JH, Sleiman PM, Christie JD, Annaiah K, Bradfield J, Kim $\mathrm{CE}$, et al. 17q12-21 variants interact with smoke exposure as a risk factor for pediatric asthma but are equally associated with early-onset versus late-onset asthma in North Americans of European ancestry. J Allergy Clin Immunol. 2009;124(3):605-7.

165. Meyers DA, Postma DS, Stine OC, Koppelman GH, Ampleford EJ, Jongepier H, et al. Genome screen for asthma and bronchial hyperresponsiveness: interactions with passive smoke exposure. J Allergy Clin Immunol. 2005;115(6):1169-75.

166. Panasevich S, Lindgren C, Kere J, Wickman M, Pershagen G, Nyberg F, et al. Interaction between early maternal smoking and variants in TNF and GSTP1 in childhood wheezing. Clin Exp Allergy. 2010;40(3):458-67.

167. Schultz EN, Devadason SG, Khoo SK, Zhang G, Bizzintino JA, Martin AC, et al. The role of GSTP1 polymorphisms and tobacco smoke exposure in children with acute asthma. J Asthma. 2010;47(9):1049-56.

168. Minelli C, Granell R, Newson R, Rose-Zerilli MJ, Torrent M, Ring SM, et al. Glutathione-S-transferase genes and asthma phenotypes: a Human Genome Epidemiology (HuGE) systematic review and meta-analysis including unpublished data. Int $\mathbf{J}$ Epidemiol. 2010;39(2):539-62. 